\title{
Effect of particulate matter (PM 10) pollutant concentration on peak expiratory flow rate score in junior high school students
}

\author{
Niken Sawitri, MD; Oma Rosmajudi, MD; Dedi Subardja, MD; Heda Melinda D N, MD
}

\begin{abstract}
Background Various pollutants especially particulate matter with diameter of 10 micrometer or less (PM 10) reduce the function of lung. However, its effect to peak expiratory flow rate (PEFR) as a parameter of central airway resistance is still inconsistent.

Objective This study was designed to assess the impact of different PM 10 concentration to PEFR score among junior high school students who live in two areas.

Methods It was a descriptive analytical study with cross sectional design to junior high school students who lived in areas with high PM 10 i.e, Cililin sub district $\left(252.63 \mathrm{mg} / \mathrm{m}^{3} / \mathrm{h}\right)$ and low PM 10 i.e., Paseh sub district $\left(27.15 \mathrm{mg} / \mathrm{m}^{3} / \mathrm{h}\right)$. PEFR was measured by using Mini Wright Peak Flow Meter and body weight by microtoire. Data of indoor pollutants were collected from questionnaires.

Results There were 463 subjects, 242 students in Cililin and 221 students in Paseh, who fulfilled the inclusion criteria which were aged $12-15$ years, living more than one years continuously within radius of $5 \mathrm{~km}$ from the location of pollutant measurement, non smokers, and considered "health" according to history taking and physical examination. The PEFR score in Cililin $(305.9+57.9 \mathrm{l} / \mathrm{min})$ was significantly lower than that in Paseh (327.7+54.8 I/min ( $\mathrm{t}=4.15$; $\mathrm{p}<0.001)$ ).

Conclusion Although the influence of indoor pollutants especially cooking stoves could not be ignored, the difference of PEFR score in these two groups were possibly due to the different concentration of PM 10 [Paediatr Indones 2003;43:66-69].
\end{abstract}

Keywords: particulate matter, peak expiratory flow rate (PEFR).

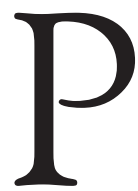
opulation in developing countries increases at a rapid rate, as does their consumption of energy. The energy for industry, domestic use, and transportation releases various pollutants into the atmosphere, including sulphur oxides $\left(\mathrm{SO}_{2}\right.$ and $\mathrm{SO}_{3}$ ), nitrogen oxides $\left(\mathrm{NO}\right.$ and $\mathrm{NO}_{2}$ ), carbon monoxide $(\mathrm{CO})$, and particulate matter with diameter of 10 micrometer or less (PM 10). These pollutants especially PM 10 can accumulate and reach toxic level in cities undergoing rapid growth of industrialization, transportation and population. ${ }^{1,2}$ Elevated air pollution especially particulate and $\mathrm{SO}_{2}$ is associated with a decline in lung function as measured by peak expiratory flow (PEF) and also is associated with increasing symptoms in respiratory health in children. ${ }^{2,3}$ In our study, we only determined the effect of particulate PM 10 to lung function in "healthy" subjects.

The aim of this study was to investigate changes in lung function, especially central airways resistance as measured by PEF, in order to know the effect of PM 10 pollution on subjects (junior high school students) living in two areas with different concentration of PM 10.

From the Department of Child Health, Medical School, Padjadjaran University, Hasan Sadikin General Hospital, Bandung.

Reprint requests to: Niken Sawitri, MD. Department of Child Health, Medical School, Padjajaran University, Bandung, Indonesia. Tel. 62-222011282. Fax. 62-22-203 2216. 


\section{Methods}

The study was done from January until February 2002 at sites that represented areas of high and low exposure of PM 10 based on data from Badan Pengendalian Dampak Lingkungan Daerah (Bapedalda) Kabupaten Bandung 2001. They were Cililin subdistrict that has high air pollution $(\mathrm{PM} 10=252.63 \mathrm{mg} / \mathrm{m} 3)$ and Paseh subdistrict that has low air pollution (PM $10=27.15$ $\mathrm{mg} / \mathrm{m} 3)$.

The subjects of the study were $12-15$ yearold children who live in those areas for over one year, lived and studied within $5 \mathrm{~km}$ distance from these sites, and were non smokers. Data were collected by administrating questionnaire based on modification from Epidemiological Standardization Project ${ }^{6}$ to parents and students. Selection of the reference population was carried out according to the "healthy" child criteria of the GAP Committee ? Anthropometric data were measured by microtoires.
Trained technicians tested each student with the MWPFM from Clement-Clarke International Ltd. London England. Each child was instructed to take a deep breath, secure the mouthpiece by teeth, make a tight seal with his/her lips, and blow out quickly and forcefully into the instrument. All tests were carried out in standing position three times and the highest result was taken as the peak expiratory flow rate (PEFR) of the subject.

\section{Results}

There were 242 students (28.7\%) in high pollution area and 221 students (35.5\%) in low pollution area who fulfilled the inclusion criteria. Characteristics of both groups (sexes, ages, and heights) did not differ significantly (Table 1 ).

We examined three potential sources of indoor pollutants which might influence the lung function e.g. cooking stoves, mosquito repellents and tobacco smoker in house ${ }^{8}$.

Table 1. Comparison of SUbJect Characteristics

\begin{tabular}{lllllll}
\hline & \multicolumn{7}{l}{ Low pollution } & \multicolumn{7}{l}{ High pollution } & \\
\cline { 2 - 7 } Variables & $\mathbf{n}$ & $\%$ & $\mathbf{n}$ & $\%$ & $\mathbf{X}$ & $\mathbf{p}$ \\
\hline 1. Sex & & & & & 0.078 & 0.78 \\
$\quad$ Male & 83 & 37 & 95 & 39 & & \\
$\quad$ Female & 138 & 63 & 147 & 61 & & \\
& & & & & & \\
2. Age (year) & & & & & & \\
12 & 39 & 18 & 55 & 23 & 6.146 & 0.105 \\
13 & 76 & 34 & 96 & 40 & & \\
14 & 79 & 36 & 73 & 30 & & \\
15 & 27 & 12 & 18 & 7 & & \\
& & & & & & \\
3. Height (cm) & & & & & & \\
$<135$ & 6 & 3 & 10 & 4 & 9.036 & \\
$135-140$ & 17 & 8 & 23 & 10 & & \\
$140-145$ & 47 & 21 & 56 & 23 & & \\
$145-150$ & 47 & 21 & 71 & 29 & & \\
$150-155$ & 62 & 28 & 51 & 21 & & \\
$>155$ & 40 & 19 & 30 & 13 & & \\
\hline
\end{tabular}

Table 2. Mean, median, minimal value and maximal value PEF of all subjects

\begin{tabular}{llll}
\hline & \multicolumn{3}{c}{ PEFR $(\mathrm{I} / \mathrm{m})$} \\
\cline { 2 - 3 } & Low pollution $\mathrm{n}=221$ & High pollution $\mathrm{n}=242$ & \\
\hline $\mathrm{X}(\mathrm{SD})$ & $327.7(54.8)$ & $305.9(57.9)$ & $\mathrm{t}=4.15$ \\
Median & 320 & 300 & $\mathrm{p}<0.001$ \\
Range & $220-480$ & $200-580$ & \\
\hline
\end{tabular}


TABLE 3. INDOOR AIR POLLUTANTS

\begin{tabular}{|c|c|c|c|c|c|c|}
\hline \multirow[b]{2}{*}{ Variables } & \multicolumn{2}{|c|}{ Low pollution } & \multicolumn{2}{|c|}{ High pollution } & \multirow[b]{2}{*}{$\mathrm{X}^{2}$} & \multirow[b]{2}{*}{ p } \\
\hline & $\mathbf{n}$ & $\%$ & $\mathbf{n}$ & $\%$ & & \\
\hline Cooking fuels & & & & & 9.91 & 0.019 \\
\hline Woods & 16 & 7 & 38 & 16 & & \\
\hline Kerosene & 189 & 86 & 182 & 75 & & \\
\hline Gas & 15 & 7 & 22 & 9 & & \\
\hline Mosquito repellents & & & & & 1.72 & 0.42 \\
\hline Mosquito coils & 170 & 86 & 186 & 83 & & \\
\hline Aerosol repellents & 23 & 12 & 30 & 13 & & \\
\hline Fumigation mat & 4 & 2 & 9 & 4 & & \\
\hline \multicolumn{7}{|l|}{ Tobacco smoke- } \\
\hline Smokers in house & & & & & 0.06 & 0.81 \\
\hline Yes & 177 & 80 & 197 & 82 & & \\
\hline No & 44 & 20 & 45 & 18 & & \\
\hline Dose of cigarettes & & & & & 8.85 & 0.56 \\
\hline$<3$ & 127 & 72 & 125 & 63 & & \\
\hline $3-10$ & 30 & 17 & 55 & 29 & & \\
\hline$>10$ & 20 & 11 & 17 & 8 & & \\
\hline
\end{tabular}

\section{Discussion}

Based on data from Bapedalda 2001, Cililin subdistrict showed a high concentration of PM 10, because in this location, air pollutants were trapped in the valley. Paseh subdistrict showed a low concentration of PM 10 but concentration of $\mathrm{SO}_{2}$, $\mathrm{NO}_{2}, \mathrm{CO}$ and $\mathrm{O}_{3}$ in both areas are similar and were below the national ambient air quality standard. We assumed that this condition has been occurring for a long time.

There were no differences in almost all indoor pollutants in both areas, except for wood stove (in low pollution areas was 7\% and in high pollution areas was $16 \%)$. It was assumed that all indoor factors which might influence the PEFR among both groups were not significantly different.

The results of our study indicated that PEFR among children who lived in high pollution area were consistently lower than those who lived in low pollution area $(\mathrm{p}<0.001)$. This condition was similar with Pope's study which only observed the association between PEFR and PM 10. ${ }^{3}$ The average predicted PEFR in high pollution area was $6.65 \%$ less than those in low pollution area.

Nevertheless, the difference of PEFR between those two groups was associated with the differences in concentration of PM 10. The result of this study was in accordance with Pope's study (1991) in healthy elementary students, but it was different with the study by Asgari (1998) in Iran. This difference might due to the difference levels of $\mathrm{SO}_{2}, \mathrm{NO}_{2}$, and PM 10. 1

As a conclusion, higher pollutant levels area was associated with lower PEFR among junior high school students (aged $12-15$ years) in Bandung district. Further research is needed to discover the effect of another pollutant to lung function among symptomatic and asymptomatic children.

\section{References}

1. Asgari MM, Dubois A, Gent J, Beckett. Association of ambient air quality with children's lung function in urban and rural Iran. Arch Environ Health 1998;53:222-30.

2. Bascom R, Bomberg PA, Hill C, Costa, Devlin R, Dockery $\mathrm{D}$ et al. Health effects of outdoor air pollution. Am J Respir Crit Care Med 1998;153:3-50.

3. Pope CA, Dockery DW, Spengler JD, Raizenne. Respiratory health and PM 10 pollution a daily time series analysis. Am Rev Respir Dis 1991;141:668-74.

4. Alsagaff $\mathrm{H}$, Mangunnegoro $\mathrm{H}$. Nilai normal faal paru orang Indonesia pada usia sekolah dan pekerja dewasa berdasarkan rekomendasi American thoracic Society. Surabaya. Airlangga University Press; 1993. 
5. Azizi B H, Henry. Effects of indoor air pollution on lung function of primary school children in Kuala Lumpur. Pediatr Pulmonol 1990;9:24-9.

6. Price SA, Wilson L M. Pathophysiology, Clinical concepts of disease processes. $4^{\text {th }}$ ed. Mc Graw-Hill; 1992. p. 540-1.
7. Ferris BG. Epidemiological standardization project. Am Rev Respir Dis 1978;18:1-53.

8. Taussig LM, Chernick V, Wond R, Farrel P, Mellins R. Standardization of lung function testing in children. J Pediatr 1980; 97:668-76. 